\title{
INVESTIGATION OF THE STRUCTURE AND PROPERTIES OF COLD-ROLLED STRIPS FROM EXPERIMENTAL ALLOY 1580 WITH A REDUCED SCANDIUM CONTENT
}

\author{
Konstantinov I.L. ${ }^{1}$, Baranov V.N. ${ }^{2}$, Sidelnikov S.B. ${ }^{1}$, Kulikov B.P. ${ }^{3}$, Bezrukikh A.I. ${ }^{4}$, Frolov V.F. ${ }^{5}$, \\ Orelkina T.A. ${ }^{6}$, Voroshilov D.S. ${ }^{1 *}$, Yuryev P.O. ${ }^{3}$, Belokonova I.N. ${ }^{1}$ \\ ${ }^{1}$ Department of Metal forming, School of Non-Ferrous Metals and Material Science «Siberian \\ federal university», Krasnoyarsk, 660025, Krasnoyarsk Region, Russia \\ ${ }^{2}$ Department of Joint metallurgy, School of Non-Ferrous Metals and Material Science «Siberian \\ federal university», Krasnoyarsk, 660025, Krasnoyarsk Region, Russia \\ ${ }^{3}$ School of Non-Ferrous Metals and Material Science «Siberian federal university», Krasnoyarsk, \\ 660025, Krasnoyarsk Region, Russia \\ ${ }^{4}$ Department of Foundry production, School of Non-Ferrous Metals and Material Science «Siberian \\ federal university», Krasnoyarsk, 660025, Krasnoyarsk Region, Russia \\ ${ }^{5}$ LLC "RUSAL ETC”, Krasnoyarsk, 660111, Krasnoyarsk Region, Russia \\ ${ }^{6}$ Department of Metal Science and Heat Treatment of Metals named after V.S. Biront, School of \\ Non-Ferrous Metals and Material Science «Siberian federal university», Krasnoyarsk, 660025, \\ Krasnoyarsk Region, Russia \\ *E-mail: d.s.voroshilov@gmail.com
}

\section{Abstract}

The structure and properties of cold-rolled strips with a thickness of $3 \mathrm{~mm}$ from an experimental aluminum alloy 1580 with a lower scandium content of $0.03 \%$ (wt.) relative to the grade of the aluminum alloy and a 5083 similar alloy without scandium were studied. Ingots obtained at the laboratory installation of semi-continuous casting of the Foundry department of the Siberian Federal University (Siberian Federal University, Russia, Krasnoyarsk) were used. The preparation of ingots for rolling included milling up to sizes $40 \times 100 \times 145 \mathrm{~mm}$ and annealing according to a two-stage mode: at a temperature of $350{ }^{\circ} \mathrm{C}$ for 3 hours (first stage) and at a temperature of $425^{\circ} \mathrm{C}$ for 4 hours (second stage). Hot rolling was carried out in the laboratory of the Department of Metal Forming at the Siberian Federal University at a temperature of $450{ }^{\circ} \mathrm{C}$ on a two-roll hot rolling mill with a roll diameter of $330 \mathrm{~mm}$ and a barrel length of $520 \mathrm{~mm}$ to a thickness of $5 \mathrm{~mm}$, which corresponded to a total reduction of $88 \%$ with a single reduction of 2-5\%. For cold rolling, a two-roll sheet rolling mill with a roll diameter of $200 \mathrm{~mm}$ and a barrel length of $400 \mathrm{~mm}$ grade LS 400 AUTO was used. Rolling was carried out to a thickness of $3 \mathrm{~mm}$ with a single reduction of $2-5 \%$, and then the strip was annealed. The results of determining the mechanical properties by tension by the universal LFM400 machine showed that with an increase in the annealing temperature in the range from 250 to $350{ }^{\circ} \mathrm{C}$ for 3 hours, ultimate tensile strength of the cold-rolled strips of aluminum alloy 1580 decreases from 385 to $365 \mathrm{MPa}$. For aluminum alloy 5083, a decrease in this strength characteristic is also observed from 345 to $320 \mathrm{MPa}$. A decreasing tendency with increasing annealing temperature was also observed for the conditional yield strength $R_{p}$, and over the entire range of annealing temperatures, the values of $R_{p}$ for strips of alloy 1580 were higher than for alloy 5083 by $35-40 \mathrm{MPa}$, which amounted to $14-17 \%$ The values of the plastic properties, for which the value of the elongation to failure was analyzed, were close throughout the range of annealing temperatures for both alloys. The results of the analysis of microand fine structure allowed to conclude that an increase in the strength properties of cold-rolled and annealed sheets from the experimental alloy 1580, compared with alloy 5083, is a consequence of the addition of scandium in the experimental alloy 1580, which leads to an increase in the temperature of recrystallization of the alloy, preserving it contains a subgrain structure and dispersion hardening caused by precipitation of $\mathrm{Al}_{3}(\mathrm{Sc}, \mathrm{Zr})$ phase particles during decomposition of a solid solution.

Keywords: Aluminum alloys, Scandium, Semi-continuous casting, Sheet rolling, Strip, Annealing, Structure, Mechanical properties. 


\section{Introduction}

Recently, there has been great interest in research aimed at improving the strength properties of alloys of the aluminum-magnesium system, which belong to the group of thermally unstrengthened aluminum alloys. These alloys have a unique combination of properties, such as reduced density, corrosion resistance, weldability, high processability in pressure processing, which is why they are extremely popular in many industries, especially in transport engineering (shipbuilding, automotive, etc.) [1-3]. The main mechanisms for hardening the alloys of this system are solid solution hardening and cold deformation. The first mechanism is realized by introducing magnesium into a solid solution, the maximum content of which in these alloys is about $6.5 \%$ (wt.). The main disadvantages of the second type of hardening are: reduced ductility $(\delta=6-9 \%)$, reduced strength of the material in the welding zone and the inability to use it for most deformed semi-finished products, except for sheets and plates. Thus, to increase the strength characteristics, it is necessary to search for effective ways to create new alloys by introducing rare-earth metals into their chemical composition. One of these metals is scandium. The addition of scandium to Al-Mg alloys increases the ultimate tensile strength and yield strength. In this case, the elongation to failure remains at a fairly high level. Numerous works have been devoted to studies of the preparation, processing, and properties of alloys with different scandium contents [431]. The authors explain the hardening of aluminum - magnesium alloys from the addition of scandium by the result of the formation of a subgrain structure in the alloys and the course of dispersion hardening due to the high degree of dispersion and distribution density in the matrix of the solid solution of thermally stable $\mathrm{Al}_{3} \mathrm{Sc}$ particles [4-9, 20, 25, 28]. Scandium also effectively prevents recrystallization, which makes it possible to produce all types of sheet metal, including thin cold-rolled sheets with a high degree of total reduction during cold rolling and a completely unrecrystallized structure after technological heating [10-14]. An example of such alloys are Russian aluminum alloys 1570 and 1580, in which the content of scandium is, respectively, 0.17 0.27 , and $0.05-0.14 \%$ (wt.). The technology for producing flat products from these alloys is described in [32-40]. However, with the positive effect of scandium on increasing strength, the high cost of this metal limits the widespread use of these alloys. Therefore, it is of interest to study the properties of alloy 1580, in which the content of scandium will be below the boundary regulated by the standard for its chemical composition, and therefore the alloy itself will therefore become cheaper. In addition, increasing the strength properties of the alloy will reduce the mass of parts made from it, which will also make it possible to improve economic performance from its use in new designs. In this work, the addition of scandium in alloy 1580 was $0.03 \%$ (wt.), and to compensate for the decrease in the content of scandium, $0.1 \%$ (wt.) zirconium was added to the alloy. Further this alloy will be called the experimental alloy 1580 .

Therefore, the aim of the work was to study the casting modes of ingots, the manufacturability of their rolling, as well as the structure and properties of flat products obtained from experimental 1580 alloy.

To achieve this goal, the following tasks were solved:

- development of modes of semi-continuous casting of an experimental alloy 1580 with a reduced content of scandium to $0.03 \%$ (wt.);

- evaluation of the processability of processing an ingot of prototype 1580 alloy during hot and cold rolling;

- study of the influence of annealing modes on the structure and mechanical properties of coldrolled products from the experimental alloy 1580;

- comparison of the mechanical properties of deformed semi-finished products from the experimental alloy 1580 with the properties of the alloy 5083 which is an analogue of alloy 1580 , but not containing scandium.

\section{Method of carrying out research}


Research on the development of the regimes for producing ingots from prototype 1580 alloy was carried out at the semi-continuous casting unit (SCCU) of the laboratory Department of Foundry production of the Siberian Federal University (Russia, Krasnoyarsk). SCCU was created with the support of RUSAL Bratsk in the framework of the implementation of the Decree of the Government of the Russian Federation No. 218 on the creation of high-tech industries under an agreement with the Ministry of Science and Higher Education (Agreement No. 03.G25.31.0265 on the theme "Development of economically alloyed high-strength Al-Sc alloys for use in road transport and navigation").

The purpose of the SCCU was to develop technologies for the preparation and casting of ingots from aluminum alloys, including experimental ones. The casting conditions at this installation in their parameters must correspond to the conditions of industrial casting of billets intended for hot and cold rolling in production conditions. The general view of the installation is shown in Fig. 1.

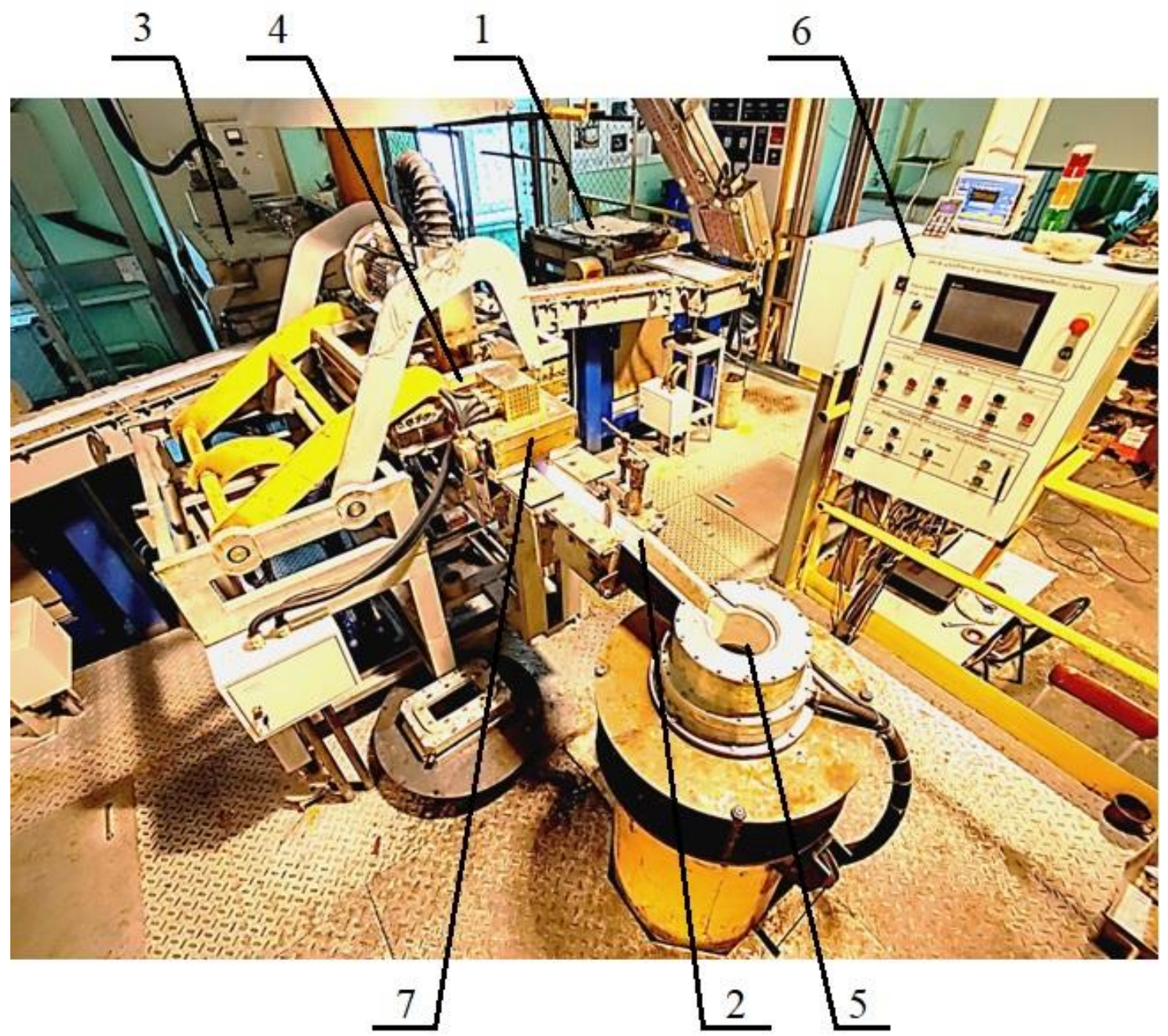

Fig. 1. Semi-continuous casting laboratory unit: 1 - induction furnace; 2 - tray system; 3 - mixer; 4 - unit for filtering liquid metal; 8 -slip mold; 6 - control system; 7 - heating tray lids for liquid metal

SCCU consists of an induction furnace 1, a system of trays 2 for liquid metal, a rotary electric mixer 3, a unit for filtering liquid metal 4, a vertical casting machine with a slip mold 5, a control system 6 , and heating tray lids for liquid metal 7.

The unit has the following specifications:

- the maximum temperature in the induction furnace brand IAT-0.16 is $1400{ }^{\circ} \mathrm{C}$;

- maximum mixer capacity for aluminum $110 \mathrm{~kg}$;

- maximum melt temperature in the mixer $900{ }^{\circ} \mathrm{C}$; 
The installation is universal and designed for the production of flat ingots of rectangular cross section with dimensions of $60 \times 200 \mathrm{~mm}$ and $86 \times 180 \mathrm{~mm}$, as well as ingots of cylindrical shape with section diameters of 190 and $60 \mathrm{~mm}$. The length of cast ingots is up to $1.2 \mathrm{~m}$.

To solve the problems posed in this work, $60 \times 200 \mathrm{~mm}$ rectangular ingots were cast on SCCU from experimental alloy 1580 and alloy 5083, which is an analogue of alloy 1580 but not containing scandium. The chemical composition of the alloys is given in Table 1 .

Table 1 - The chemical composition of the experimental alloys, \% (wt.)

\begin{tabular}{|l|c|c|c|c|c|c|c|c|c|c|}
\hline Alloys & $\mathrm{Si}$ & $\mathrm{Fe}$ & $\mathrm{Mn}$ & $\mathrm{Mg}$ & $\mathrm{Cr}$ & $\mathrm{Ti}$ & $\mathrm{Zr}$ & $\mathrm{Sc}$ & $\mathrm{V}$ & $\mathrm{Al}$ \\
\hline 1580 & 0.08 & 0.16 & 0.5 & 5.3 & 0.15 & 0.02 & 0.10 & 0.03 & 0.01 & Basis \\
\hline 5083 & 0.045 & 0.17 & 0.6 & 4.5 & 0.15 & - & - & - & - & Basis \\
\hline
\end{tabular}

For the preparation of alloys aluminum grade A85 were used, as well as alloying and modifying additives, the characteristics of which are given in Table 2.

Table 2 - The chemical composition of ligatures and other alloying additives, $\%$ (wt.)

\begin{tabular}{|c|c|c|c|c|c|c|c|c|c|c|c|}
\hline \multirow[b]{2}{*}{$\begin{array}{l}\text { Ligature } \\
\text { mark }\end{array}$} & \multicolumn{9}{|c|}{ The content of elements, $\%$ (wt.) } & \multicolumn{2}{|c|}{ Other elements } \\
\hline & $\mathrm{Si}$ & $\mathrm{Fe}$ & $\mathrm{Mn}$ & Sc & $\mathrm{Zr}$ & $\mathrm{V}$ & $\mathrm{Cr}$ & $\mathrm{Ti}$ & B & $\begin{array}{c}\text { Each } \\
\text { no more }\end{array}$ & $\begin{array}{l}\text { Amount } \\
\text { no more }\end{array}$ \\
\hline $\operatorname{AlMn} 10(\mathrm{~A})$ & 0.3 & 0.4 & $9.0-11.0$ & - & - & - & - & 0.03 & - & 0.04 & 0.1 \\
\hline $\mathrm{AlCr} 10$ & 0.2 & 0.3 & 0.05 & - & - & - & $\begin{array}{l}9.0- \\
11.0\end{array}$ & 0.03 & - & 0.04 & 0.1 \\
\hline $\operatorname{AlSc} 2(\mathrm{~A})$ & 0.05 & 0.05 & 0,01 & $1.7-2.3$ & - & - & - & - & - & 0.04 & 0.1 \\
\hline AlZr10(A) & 0.2 & 0.3 & 0.05 & - & $\begin{array}{l}9.0- \\
11.0\end{array}$ & - & - & - & - & 0.04 & 0.1 \\
\hline Al-Ti5-B1 & 0.2 & 0.3 & - & - & - & - & - & $\begin{array}{c}4.5- \\
5.5\end{array}$ & $\begin{array}{c}0.9- \\
1.1 \\
\end{array}$ & 0.04 & 0.1 \\
\hline $\mathrm{Al}-\mathrm{Fe} 20$ & 0.3 & $18-20$ & 0.2 & - & - & - & - & - & - & - & 0.1 \\
\hline Al-V5 & 0.3 & 0.4 & 0.15 & - & - & $\begin{array}{r}4.0- \\
6.0 \\
\end{array}$ & - & - & - & 0.04 & 0,1 \\
\hline Мг90 & 0.009 & 0.04 & 0.03 & - & - & - & - & - & - & 0.01 & 0.1 \\
\hline Кр00 & 99.4 & 0.4 & - & - & - & - & - & - & - & - & 1.0 \\
\hline
\end{tabular}

The calculation of the amount of alloying additives was carried out according to the computer program developed by the authors, into which the initial data on the mass of the obtained alloy (kg) and its chemical composition (\%), as well as on the composition of the starting metal, alloying and modifying additives $(\%)$ were introduced. As a result of the calculation, the necessary amount of charge materials $(\mathrm{kg})$ was obtained to prepare the required volume of alloy with a given chemical composition.

In this work, the amount of alloy per melt was $60 \pm 0.1 \mathrm{~kg}$. The estimated amount of aluminum was melted in an induction furnace IAT-0.16. During the preparation of the alloy, alloying additives were successively introduced into liquid aluminum at a certain temperature and dissolution time. The concentration of the main and impurity elements was determined on a Foundry master lab optical emission spectrometer.

The temperature in the induction furnace was $850 \pm 10{ }^{\circ} \mathrm{C}$, and after the melt overflow into the mixer, it dropped to $700-710{ }^{\circ} \mathrm{C}$, after which the metal entered the slip mold. Ingots from two experimental alloys were obtained at the same temperature and speed casting parameters, after which the bottom and gate parts $(100 \mathrm{~mm}$ each $)$ were cut off.

Preparation of ingots from prototype alloy 1580 and alloy 5083 for rolling included milling up to dimensions $40 \times 100 \times 145 \mathrm{~mm}$ (Fig. 2) and two-stage annealing at a temperature of $350{ }^{\circ} \mathrm{C}$ for 3 hours (first stage) and at a temperature of $425^{\circ} \mathrm{C}$ for 4 hours (second stage), which 
was carried out in a furnace PP 20/65, providing uniform heating of the ingots, due to the horizontal circulation of the internal atmosphere.

Hot rolling was carried out in the laboratory of the Department of Metal Forming of the Siberian Federal University on a two-roll hot rolling mill with a roll diameter of $330 \mathrm{~mm}$ and a barrel length of $520 \mathrm{~mm}$ at a temperature of $450{ }^{\circ} \mathrm{C}$ to a thickness of $5 \mathrm{~mm}$, which corresponded to a total reduction of $88 \%$. Single reduction during rolling was $2-5 \%$. In order to avoid cooling the ingots below a temperature of $390{ }^{\circ} \mathrm{C}$, after every two passes, the ingots were heated to a temperature of $450^{\circ} \mathrm{C}$.

For cold rolling, a two-roll sheet rolling mill with a roll diameter of $200 \mathrm{~mm}$ and a barrel length of $400 \mathrm{~mm}$ of the LS 400 AUTO brand from "Mario Di Maio" was used. Hot-rolled strips were rolled to a thickness of $3 \mathrm{~mm}$ with single reductions from 2 to $5 \%$.

It should be noted that during hot rolling and especially cold rolling, due to limitations imposed by the power capabilities of the laboratory rolling mill, the authors could not apply the maximum possible degrees of deformation for these alloys, but limited to single reductions of 2 $5 \%$. But at the same time, which is especially important when comparing properties for two alloys, the same rolling conditions were observed.

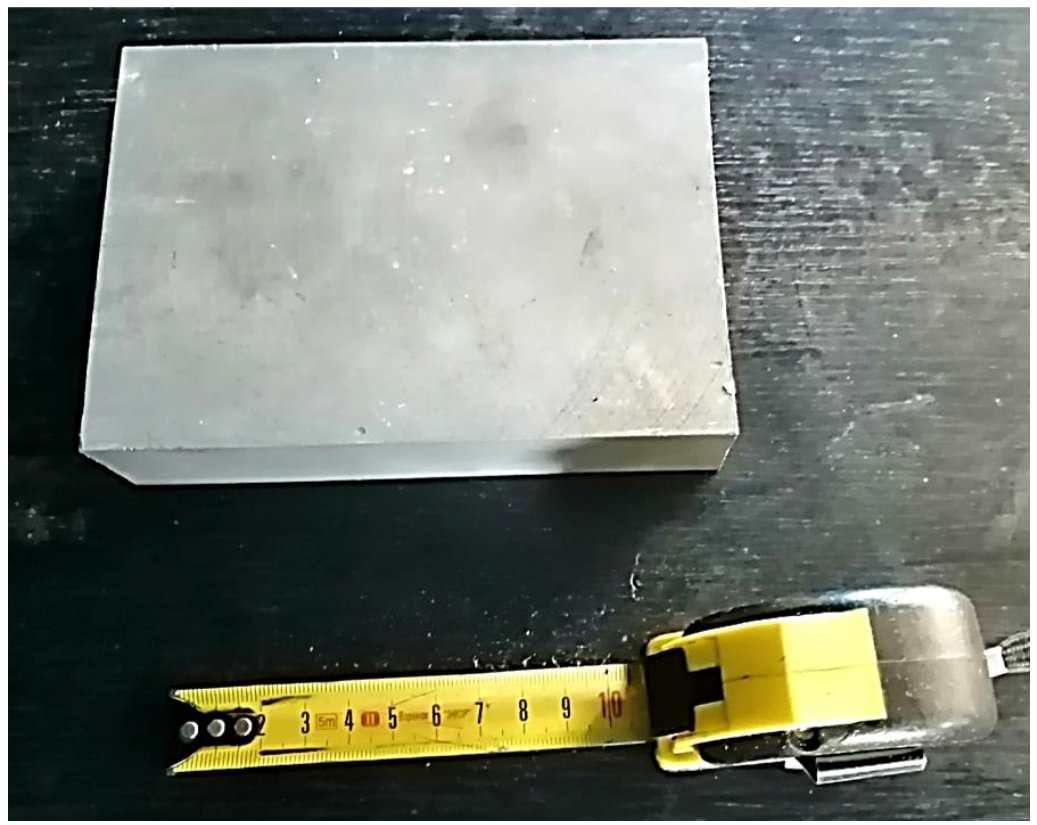

Fig. 2. Ingot for rolling

Samples for testing tensile mechanical properties according to State Standard 1497-84 were made from cold-rolled strips, which were carried out on a universal testing machine Walter+Bai AG LFM $400 \mathrm{kN}$ (Walter+Bai AG, Switzerland). Cutting of samples was carried out across the rolling direction. Before testing, the samples were annealed at temperatures of 250, 275,300 , and $350^{\circ} \mathrm{C}$. In all cases, the shutter speed was 3 hours. In tests on one point, 3 samples were taken. The test results were subjected to statistical processing. Microstructure studies were performed using an Observer light microscope A1m and a Carl Zeiss EVO 50 electron microscope. The microstructure of the sheets in the annealed state after deposition of the oxide film was studied using polarized light. The fine structure of the alloys was investigated using a Technai $30 \mathrm{G} 2$ transmission electron microscope at an accelerating voltage of $300 \mathrm{kV}$.

\section{Results and discussion}

When studying the effect of annealing temperature on the properties of cold-rolled sheets, the authors set a goal to quantitatively determine the effect of scandium additives on the properties of experimental alloy 1580, comparing it with alloy 5083, which this element does not contain. Moreover, it was known in advance that the strength properties of the 5083 alloy will decrease with 
increasing annealing temperature, and the ductility of the alloy will increase. This character of the effect of increasing the annealing temperature on the properties of the 5083 alloy is known to be explained by the occurrence and then acceleration of recrystallization processes. In the experimental alloy 1580, scandium aluminide particles should slow down the onset and development of recrystallization to a certain temperature, and, therefore, should prevent the decrease in strength properties. The results of testing the mechanical properties of sheet metal from the experimental alloy 1580 and alloy 5083 are presented in Fig. 3. From the graphs it follows that with an increase in the annealing temperature in the range from 250 to $350{ }^{\circ} \mathrm{C}$, the tensile strength of the cold-rolled strips of $3 \mathrm{~mm}$ thick from the experimental alloy 1580 gradually decreases from 385 to $365 \mathrm{MPa}$. At the same time, a decrease in strength is also observed for alloy 5083, but at a lower level from 345 to $320 \mathrm{MPa}$. The same tendency to decrease depending on the increase in the annealing temperature is observed for strips from the studied alloys and for the conditional yield strength of the metal $R_{p}$. However, in the entire annealing temperature range, this parameter in the experimental alloy 1580 exceeds the value $R_{p}$ for the 5083 alloy by $35-40 \mathrm{MPa}$, or by approximately $14-17 \%$, and the elongation to failure of both alloys was close throughout the annealing temperature range.

In order to identify the causes of the difference in the mechanical properties of sheet metal from experimental alloy 1580 and alloy 5083, a study of the structure using polarized light was carried out, confirming that even small additives of scandium increase the temperature of the onset of recrystallization of experimental alloy 1580. The content in it has the same effect $0.1 \%$ of zirconium. Therefore, after annealing at a temperature of $250{ }^{\circ} \mathrm{C}$, the microstructure of the coldrolled strips from the experimental alloy 1580 corresponds to the unrecrystallized state and represents fibers elongated along the rolling direction (Fig. 4a). In the 5083 alloy, which does not contain Sc and $\mathrm{Zr}$, after the same annealing regime, the onset of primary recrystallization is observed and single grains are revealed in the structure (Fig. $4 b$ ).

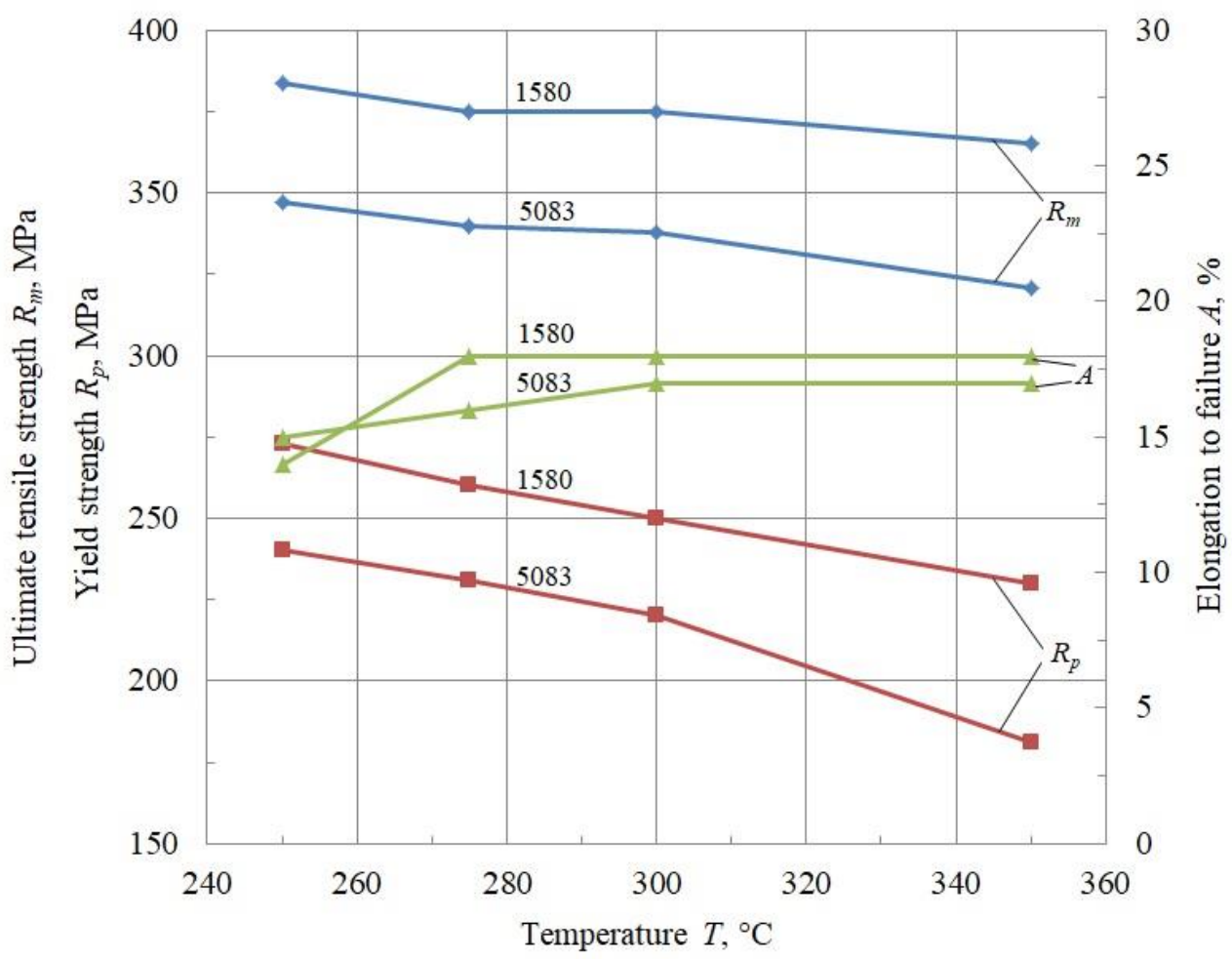

Fig. 3. The dependence of the mechanical properties of cold-rolled strips of a thickness of 3 $\mathrm{mm}$ from experimental alloys 1580 and 5083 on the annealing temperature 


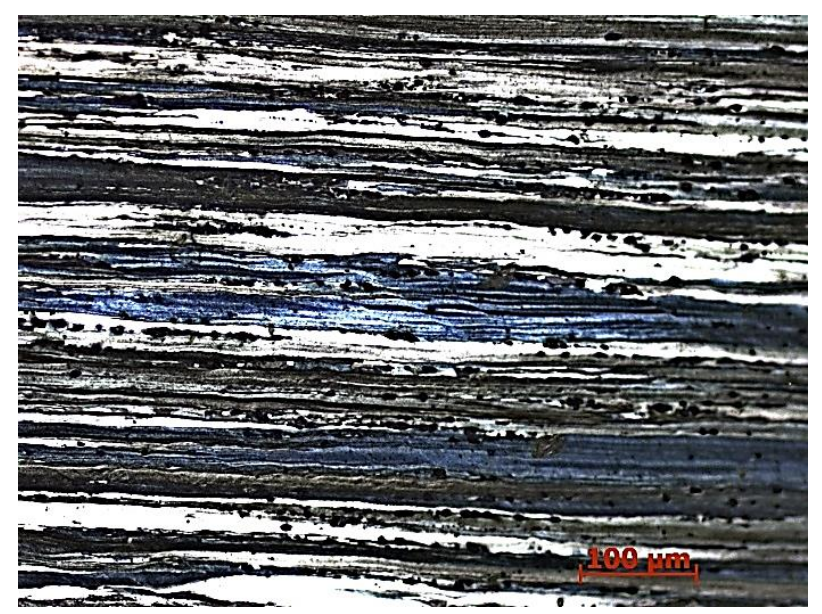

$a$

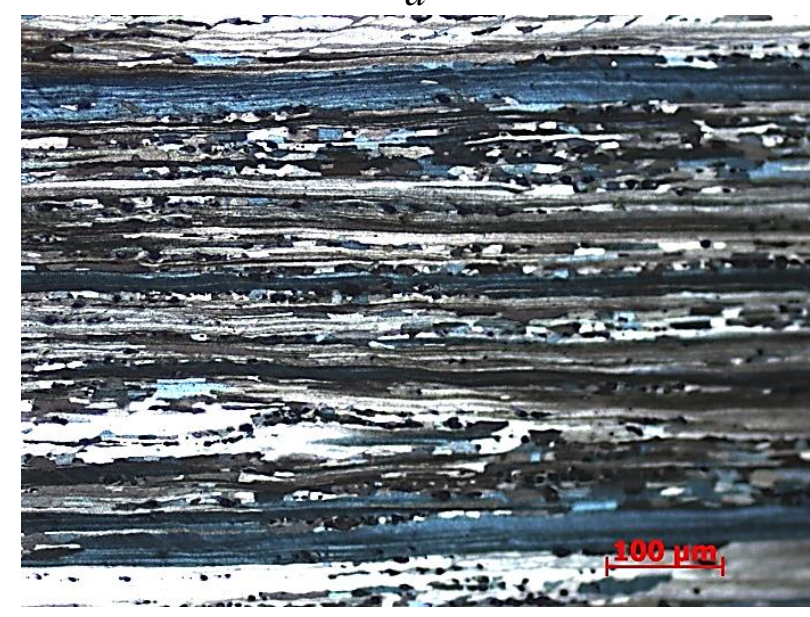

C

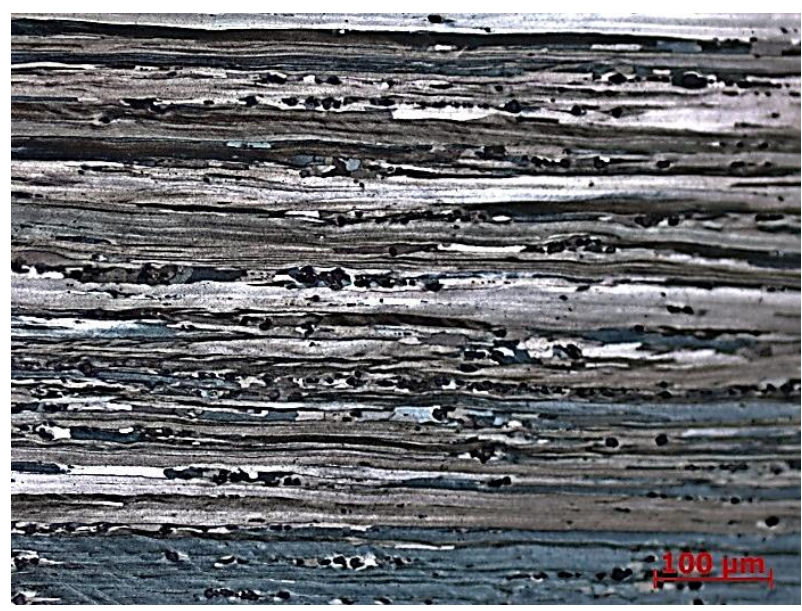

$b$

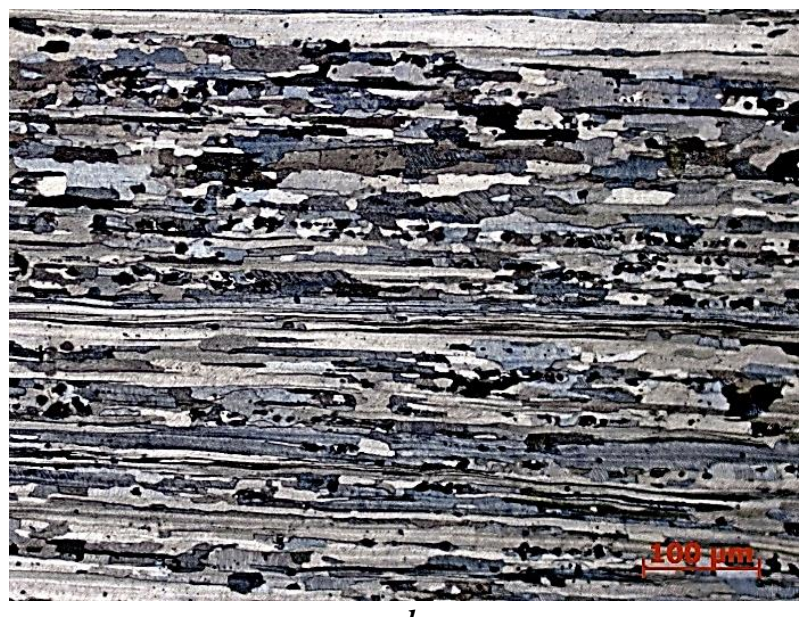

$d$

Fig. 4. Microstructure of cold-rolled strips after annealing at various temperatures: $a, b$-temperature $250^{\circ} \mathrm{C} ; c, d$-temperature $350{ }^{\circ} \mathrm{C} ; a, c$ - alloy $1580 ; b, d$ - alloy 5083

A further increase in the annealing temperature promotes the formation of new recrystallized grains in the deformed semi-finished products. Therefore, if at the annealing temperature of $275{ }^{\circ} \mathrm{C}$ only single recrystallized grains are formed in the strips of the experimental alloy 1580 , then in the strips of the 5083 alloy it is already possible to observe the further development of recrystallization in the form of recrystallized grains occupying separate volumes of the fibrous structure.

Annealing at temperatures of $300^{\circ} \mathrm{C}$ and $350{ }^{\circ} \mathrm{C}$ in the strips of the experimental alloy 1580 leads to an increase in the number of new recrystallized grains in the fiber volumes (Fig. $4 c$ ). In sheets of alloy 5083 annealed at $350{ }^{\circ} \mathrm{C}$, primary recrystallization proceeds in almost the entire volume of the metal, with the exception of single regions (Fig. $4 d$ ).

The method of diffraction transmission electron microscopy showed that upon annealing of the ingot from the experimental alloy 1580, the supersaturated solid solution decomposes into scandium and zirconium with the release of spherical $\mathrm{Al}_{3}(\mathrm{Sc}, \mathrm{Zr})$ particles with a size of about 30 $\mu \mathrm{m}$. Upon deformation and subsequent annealing of the strips from the experimental alloy 1580, a subgrain structure with separate sections of recrystallized grains mainly forms (Fig. $5 a, b$ ), which confirms the results of studies obtained by light microscopy. 


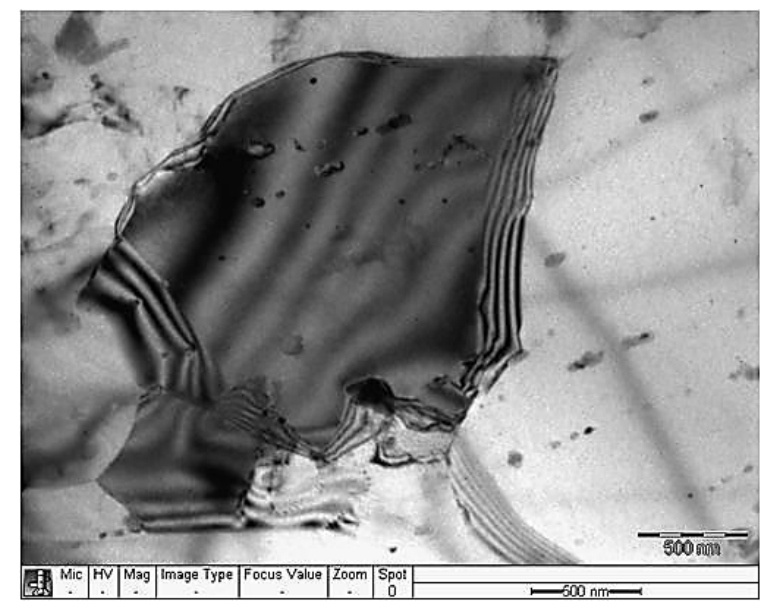

$a$

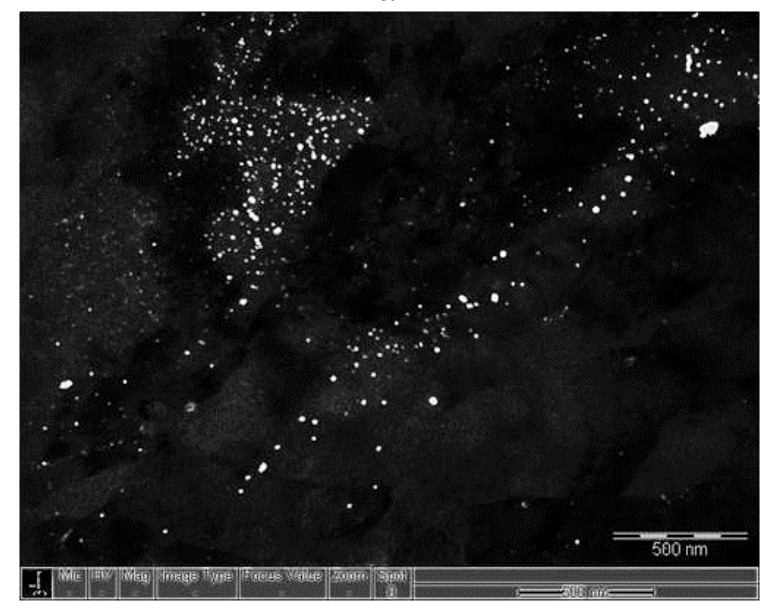

C

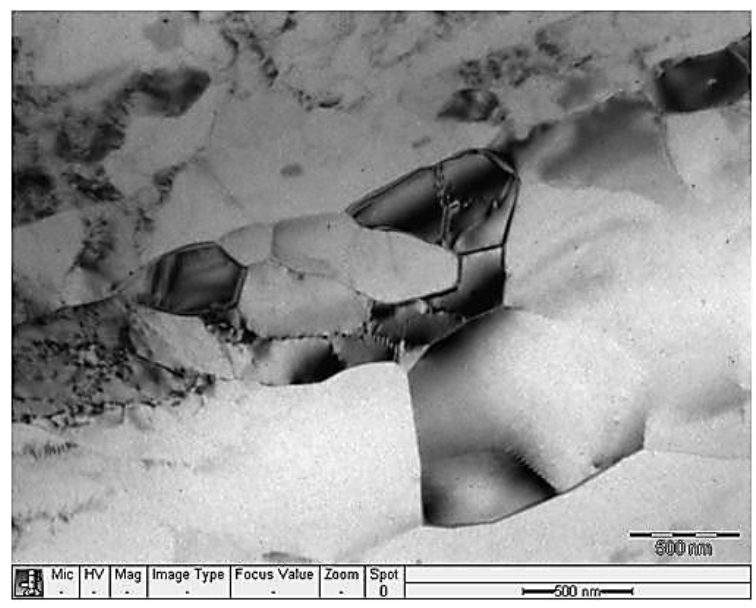

$b$

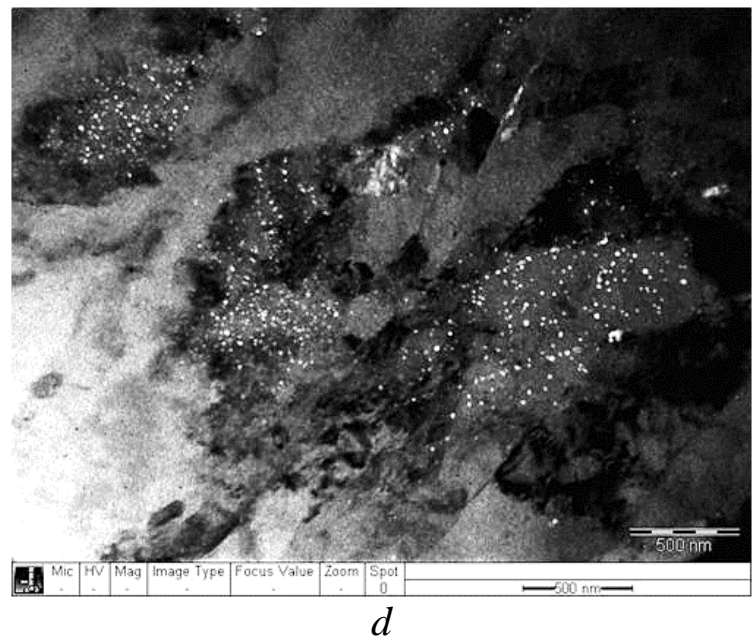

Fig. 5. Fine structure of a strip of alloy 1580 after annealing at a temperature of $275^{\circ} \mathrm{C}$ for 3 hours: $a, b$-bright field; $c, d$-dark field with the distribution of particles (bright dots) of the phases $\mathrm{Al}_{3}(\mathrm{Sc}, \mathrm{Zr})$

Inclusions of the $\mathrm{Al}_{3}(\mathrm{Sc}, \mathrm{Zr})$ phase are presented in Fig. $5 c, d$ (in the form of bright dots), as single particles in parts of a matrix with a grain structure, or as line-by-line precipitates of particles along the longitudinal boundaries of subgrains, and also as regions in a matrix with a homogeneous phase distribution. The selection of these particles provides dispersion hardening of the experimental alloy 1580 .

\section{Conclusions}

Based on the research results, the following conclusions can be drawn.

1. The modes for producing ingots from the experimental alloy 1580 with a low content of scandium in laboratory conditions of the Department of Foundry production of the Siberian Federal University on a semi-continuous casting unit were developed and implemented.

2. The parameters of hot and cold rolling of ingots from the experimental alloy 1580 were investigated in the laboratory conditions of the Department of Metal Forming of the Siberian Federal University.

3. It is shown that with annealing temperature increase in the range from 250 to $350{ }^{\circ} \mathrm{C}$, the strength properties $\left(R_{m}\right.$ and $\left.R_{p}\right)$ of cold-rolled strips from the experimental alloy 1580 are higher than that of the alloy 5083 by $14-17 \%$ at close values of the elongation to failure $(A)$.

4. An analysis of the micro- and fine structure of the metal showed that an increase in the strength properties of cold-rolled and annealed strips of the experimental alloy 1580, compared with alloy 5083, is a consequence of the scandium content in 1580 alloy in the amount of $0.03 \%$ (wt.), which leads to an increase in the recrystallization temperature of this alloy, preservation of the 
subgrain structure in sheet metal from it after annealing, and dispersion hardening caused by precipitation of $\mathrm{Al}_{3}(\mathrm{Sc}, \mathrm{Zr})$ phase particles during decomposition of the solid solution.

5. Sheet semi-finished products from a prototype aluminum alloy 1580 can be recommended for use in shipbuilding and automotive industry as parts obtained by sheet stamping, as well as for the manufacture of containers for storing liquids, etc.

\section{Acknowledgments}

The manuscript was prepared using the results of the work carried out during the project 03.G25.31.0265 "Development of economically alloyed high-strength Al-Sc alloys for use in road transport and navigation" in the framework of the Program for the implementation of complex projects for the creation of high-tech production, approved by the Government of the Russian Federation on April 9, 2010 №218.

The work is performed as a part of the state assignment for the science of Siberian Federal University, project number FSRZ-2020-0013.

Use of equipment of Krasnoyarsk Regional Center of Research Equipment of Federal Research Center «Krasnoyarsk Science Center SB RAS» is acknowledged.

\section{References}

1. A.V. Bronz, V.I. Efremov, A.D. Plotnikov, A.G. Chernyavskiy. Kosmicheskaya tekhnika i tekhnologii [Space Engineering and Technology], 2014, 4(7), 62-67.

2. Yu.A. Filatov, A.D. Plotnikov. Tekhnologiya legkikh splavov [Light alloy technology], 2011, 2, 15-26.

3. Baranov V.N., Sidelnikov S.B., Zenkin Yu.A., Frolov V.F., Voroshilov D.S., Yakivyuk O.V., Konstantinov I.L., Sokolov R.E., Belokonova I.N. Investigation of the strength properties of semi-finished products from economically alloyed high-strength aluminumscandium alloys for use in automobile transport and shipping. In the collection: Non-ferrous metals and minerals - 2017. Collection of reports of the Ninth International Congress, 2017, 717-718.

4. M.E. Drits, L.S. Toropova, Yu.G. Bykov. Metallovedenie i termicheskaya obrabotka metallov [Metallurgy and heat treatment of metals], 1980, 10, 35-37.

5. M.E. Drits, S.G. Pavlenko, L.S. Toropova et al. DAN SSSR. Metally [DAS USSR. Metals], 1981, 257(2), 353-356.

6. M.E. Drits, L.S. Toropova, Yu.G. Bykov et al. Metallurgiya i metallovedenie tsvetnykh splavov [Metallurgy and material science of non-ferrous alloys]. - M.: Nauka, 1982, 213223.

7. V.I. Elagin, V.V. Zakharov, T.D. Rostova. Prospects for alloying aluminum alloys with scandium. Tsvetnye metally, 1982, 12, 96-99.

8. M.E. Drits, Yu.G. Bykov, L.S. Toropova. Metallovedenie i termicheskaya obrabotka metallov [Metallurgy and heat treatment of metals], 1985, 4, 48-50.

9. Zakharov V.V. Metallovedenie i termicheskaya obrabotka metallov [Metallurgy and heat treatment of metals], 2014, 6, 3-8.

10. Yu.A. Filatov. VILS: Tekhnologiya legkikh splavov [RILA: Light alloy technology], 2009, 3, $42-45$.

11. V.I. Elagin, V.V. Zakharov, T.D. Rostova. Metallovedenie i termicheskaya obrabotka metallov [Metallurgy and heat treatment of metals], 1992, 1, 24-28.

12. V.G. Davydov, V.I. Elagin, V.V. Zakharov, T.D. Rostova. Tsvetnye metally i splavy [Nonferrous metals and alloys], 1996, 8, 25-30.

13. Belov N.A., Alabin A.N. Promising aluminum alloys with zirconium and scandium additives. Tsvetnye metally, 2007, 2, 99-106. 
14. Yu.A. Filatov. Metallovedenie i termicheskaya obrabotka metallov [Metallurgy and heat treatment of metals], 1996, 6, 33-36.

15. S.-I. Fujikawa, S. Sakauchi. Kinetics of Precipitation in Al-0,20 mass \% Sc Alloy. Aluminium Alloys. Their Physical and Mechanical Properties. Proc. of the 6th Int. Conf. on Aluminium Alloys, ICAA-6. Toyohashi, Japan. - The Japan Institute of Light Metals, 1998, 2, 805-810.

16. Koryagin Yu.D., Il'in S.I. Recrystallization features of deformable aluminium-magnesium alloys with scandium. Bulletin of the South Ural State University. Series "Metallurgy", $2017,17,1,65-72$.

17. Yu.A. Filatov. VILS: Tekhnologiya legkikh splavov [RILA: Light alloy technology], 2009, 3, $42-45$.

18. Chunchang Shi, Liang Zhang, Guohua Wu, Xiaolong Zhang, Antao Chen, Jiashen Tao. Effects of Sc addition on the microstructure and mechanical properties of cast Al-3Li1.5Cu-0.15Zr alloy. Materials Science \& Engineering, 2017, A680, 232-238.

19. Mengjia Li, Qinglin Pan, Yunjia Shi, Xue Sun, Hao Xiang. High strain rate superplasticity in an $\mathrm{Al}-\mathrm{Mg}-\mathrm{Sc}-\mathrm{Zr}$ alloy processed via simple rolling. Materials Science \& Engineering, 2017, A687, 298-305.

20. Yu. Buranova, V. Kulitskiy, M. Peterlechner, A. Mogucheva, R. Kaibyshev, S.V. Divinski, G. Wilde. Al3(Sc, Zr) - based precipitates in AlMg alloy: Effect of severe deformation. Acta Materialia. 2017, 124, 210-224.

21. Keith E. Knipling, David N. Seidman, David C. Dunand. Ambient- and high-temperature mechanical properties of isochronally aged $\mathrm{Al}-0.06 \mathrm{Sc}, \mathrm{Al}-0.06 \mathrm{Zr}$ and $\mathrm{Al}-0.06 \mathrm{Sc}-0.06 \mathrm{Zr}$ (at.\%) alloys. Acta Materialia, 2011, 59, 943-954

22. V. Rajinikanth, Vikas Jindal, V.G. Akkimardi, Mainak Ghosha, K. Venkateswarlu. Transmission electron microscopy studies on the effect of strain on $\mathrm{Al}$ and $\mathrm{Al}-1 \% \mathrm{Sc}$ alloy. Scripta Materialia, 2007, 57, 425-428.

23. Sheng-Long Lee, Jeng-Kuei Chang, Yin-Chun Cheng, Kent-Yi Lee, Wen-Chi Chen. Effects of scandium addition on electrical resistivity and formation of thermal hillocks in aluminum thin films. Materials characterization, 2011, 519, 3578-3581.

24. Zakharov V.V. MiTOM [MS\&MPT], 2003, 7, 7-15.

25. M.J. Jones, F.J. Humphreys. Interaction of recrystallization and precipitation: The effect of $\mathrm{Al}_{3} \mathrm{Sc}$ on the recrystallization behavior of deformed aluminium. Acta Materialia, 2003, 51(8), 2149-2159.

26. A.K. Lohara, B. Mondala, D. Rafajab, V. Klemmb, S.C. Panigrahic. Microstructural investigations on as-cast and annealed $\mathrm{Al}-\mathrm{Sc}$ and $\mathrm{Al}-\mathrm{Sc}-\mathrm{Zr}$ alloys. Materials characterization, 2009, 60, 1387-1394.

27. R. Stock, B. Köhler, H. Bomas, H.-W. Zoch. Characteristics of aluminium-scandium alloy thin sheets obtained by physical vapour deposition. Materials and Design, 2010, 31, 76-81.

28. Marquis E.A., Seidman E.A. Nanoscale structural evolution of $\mathrm{Al}_{3} \mathrm{Sc}$ precipitates in $\mathrm{Al}(\mathrm{Sc})$ alloys. Acta Materialia, 2001, 49, 1909-1919.

29. Norman A.F., Prangnell P.B., McEwen R.S. The solidification behavior of dilute aluminium-scandium alloys. Acta Materialia, 1998, 46, 5715-5732.

30. Pedro Henrique R. Pereiraa, Ying Chun Wang, Yi Huang, Terence G. Langdon. Influence of grain size on the flow properties of an Al-Mg-Sc alloy over seven orders of magnitude of strain rate. Materials Science \& Engineering, 2017, A685, 367-376.

31. S. Mondol, T. Alamb, R. Banerjee, S. Kumar, K. Chattopadhyay. Development of a high temperature high strength $\mathrm{Al}$ alloy by addition of small amounts of Sc and $\mathrm{Mg}$ to 2219 alloy. Materials Science \& Engineering, 2017, A687, 221-231.

32. Baranov V.N., Sidelnikov S.B., Zenkin E.Yu., Konstantinov I.L., Lopatina E.S., Yakivyuk O.V., Voroshilov D.S., Belokonova I.N., Frolov V.A. Study on the influence of heat treatment modes on mechanical and corrosion properties of rolled sheet products from a new 
aluminum alloy, economically alloyed with scandium. Vestnik of Nosov Magnitogorsk State Technical University, 2019, 17(1), 76-81.

33. Baranov V.N., Zenkin E.Yu., Konstantinov I.L., Sidelnikov S.B. The research of the cold rolling modes for plates of aluminum alloy sparingly doped with scandium. Non-Ferrous Metals, 2019, 47(2), 48-53.

34. Baranov V.N., Sidelnikov S.B., Frolov V.F., Zenkin E.Yu., Orelkina T.A., Konstantinov I.L., Voroshilov D.S., Yakivyuk O.V., Belokonova I.N. Vestnik gorno-metallurgicheskoy sektsii Rossiyskoy akademii estestvennykh nauk. Otdelenie metallurgii [Bulletin of the mining and metallurgical section of the Russian Academy of Natural Sciences. Metallurgy department], 2018, 41, 184-190.

35. Baranov V., Sidelnikov S., Voroshilov D., Yakivyuk O., Konstantinov I., Sokolov R., Belokonova I., Zenkin E., Frolov V. Study of strength properties of semi-finished products from economically alloyed high-strength aluminium-scandium alloys for application in automobile transport and shipbuilding. Open Engineering, 2018, 8(1), 69-76.

36. Baranov V.N., Sidelnikov S.B., Frolov V.F., Zenkin E.Yu., Orelkina T.A., Konstantinov I.L., Voroshilov D.S., Yakivyuk O.V., Belokonova I.N. Study of the mechanical properties of cold-rolled, annealed and welded semi-finished products from experimental alloys of the Al-Mg system, economically alloyed with scandium. In the collection: Metallurgy: technology, innovation, quality, proceedings of the XX International Scientific and Practical Conference: in 2 parts, 2017, 149-153.

37. Baranov V.N., Sidelnikov S.B., Zenkin E.Yu., Bezrukikh A.I., Konstantinov I.L., Sokolov R.E., Voroshilov D.S., Belokonova I.N., Yakivyuk O.V. Study of the mechanical properties of semi-finished products from aluminum-scandium alloy. Bulletin of the Tula State University, 2017, 11(1), 147-153.

38. Dovzhenko I.N., Dovzhenko N.N., Sidelnikov S.B., Konstantinov I.L. 3D modelling of the large-capacity ingots of an $\mathrm{Al}-\mathrm{Mg}$ system aluminium alloy doped with scandium rolling process. Non-Ferrous Metals, 2017, 43(2), 60-64.

39. S.B. Sidelnikov, O.V. Yakivyuk, V.N. Baranov, E.Yu. Zenkin \& I.N. Dovzhenko. Developing, Simulating, and Researching a Production Process of Long Deformed SemiFabricated Aluminum-Magnesium Products with a Varying Scandium Content. Russian Journal of Non-Ferrous Metals, 2020, 61, 81-88.

40. Vladimir N. Baranov, Sergey B. Sidelnikov, Evgeniy Yu. Zenkin, Irina N. Belokonova, Ekaterina S. Lopatina, Olga V. Yakivyuk, Denis S. Voroshilov. Study on the structure and properties of strips and plates from the alloy of the Al-Mg system, economically alloyed with scandium. Journal of Chemical Technology and Metallurgy, 2020, 55(3), 538-543. 